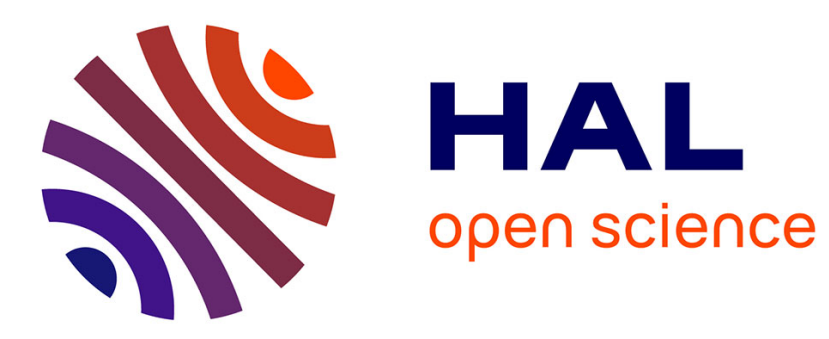

\title{
Review on clinical trials of targeted treatments in malignant mesothelioma
}

Jan Nyrop Jakobsen, Jens Benn Sørensen

\section{To cite this version:}

Jan Nyrop Jakobsen, Jens Benn Sørensen. Review on clinical trials of targeted treatments in malignant mesothelioma. Cancer Chemotherapy and Pharmacology, 2011, 68 (1), pp.1-15. 10.1007/s00280-0111655-3 . hal-00694874

\section{HAL Id: hal-00694874 \\ https://hal.science/hal-00694874}

Submitted on 7 May 2012

HAL is a multi-disciplinary open access archive for the deposit and dissemination of scientific research documents, whether they are published or not. The documents may come from teaching and research institutions in France or abroad, or from public or private research centers.
L'archive ouverte pluridisciplinaire HAL, est destinée au dépôt et à la diffusion de documents scientifiques de niveau recherche, publiés ou non, émanant des établissements d'enseignement et de recherche français ou étrangers, des laboratoires publics ou privés. 


\title{
Review on clinical trials of targeted treatments in malignant mesothelioma.
}

\author{
Jan Nyrop Jakobsen and Jens Benn Sørensen. \\ Department of Oncology, Finsencentre, Copenhagen, Denmark
}

Correspondence to:

Jan Nyrop Jakobsen

Rigshospitalet, Blegdamsvej 9, 2100

Copenhagen, Denmark

Telephone: +4535453545

Fax: +4535456966

Correspondence: jan.nyrop.jakobsen@rh.regionh.dk 


\section{Abstract:}

Purpose: Malignant mesothelioma (MM) is an aggressive tumor of the serosal surfaces with a poor prognosis. Advances in the understanding of tumor biology have led to the development of several targeted treatments, which have been evaluated in clinical trials. This article is a comprehensive review of all clinical trials evaluating the effect of targeted treatments in MM.

Methods: An extensive literature search was performed in January 2011 using pubmed and medline. No constraints on publication date were applied.

Results: 32 trials exploring 17 different targeted agents in MM were found. Treatment in $1^{\text {st }}$ and $2^{\text {nd }}$ line targeted agents induced response rates ranging from $0 \%$ to $14 \%$ and 0 to $16 \%$, respectively. The tyrosine kinase inhibitor sunitinib induced partial response in $10 \%$ and stable disease in $66 \%$ of MPM patients as $2^{\text {nd }}$ line treatment. A preliminary analysis of a phase II/III trial suggests that addition of bevacizumab to pemetrexed and cisplatin $1^{\text {st }}$ line treatment significantly improves disease control (CR+PR+SD) in the bevacizumab arm (73.5\%) compared to treatment with pemetrexed and cisplatin without bevacizumab $(43.2 \%)(p=0.010)$. Another phase II trial did not observe any significant clinical benefit of adding of bevacizumab to gemcitabine and cisplatin.

Conclusions: Disease stabilization is reported in some patients with several targeted treatments and might be beneficial in subgroups of patients or in combination with classic chemotherapy. None of the hitherto explored targeted treatments can currently be recommended as standard treatment in MM.

Conflicts of interest

Jan Nyrop Jakobsen: None

Jens Benn Sørensen: None

Keywords: Malignant mesothelioma, Malignant pleural mesothelioma, Targeted treatments. Tyrosine kinase inhibitors. 


\section{Abbreviations:}

$A B L$ - Abelson murine leukemia viral oncogene homolog

AKT - a member of the non-specific serine/threonine-protein kinase family

ALK - Anaplastic lymphoma kinase

BCR- breakpoint cluster region

CALGB - Cancer and leukemia group B

C-KIT - V-kit Hardy-Zuckerman 4 feline sarcoma viral oncogene homolog

$\mathrm{CML}$ - Chronic myeloid leukemia

CR - Complete response

EGF - Endothelial growth factor

EGFR - Endothelial growth factor receptor

EML4 - Echinoderm microtubule-associated protein-like 4

EPP - Extrapleural pneumectomy

FDG-PET - Fludeoxyglucose(18F) Positron emission tomography

GIST - Gastro intestinal stromal tumor

HDAC - Histone deacetylase

HDACi - Histone deacetylase inhibitor

IFP - Interstitial fluid pressure

IGF-1 - Insulin like growth factor 1

KDR - Kinase insert domain receptor

MM - Malignant mesothelioma

MPM - Malignant pleural mesothelioma

mTOR - mammalian target of rapamycin

NGR - Asparagine-Glycine-Arginine

hTNF - Human Tumor Necrosis Factor alpha

OS - Overall survival

PD - Progression disease

PDGF - Platelet derived growth factor

PDGFR - Platelet derived growth factor receptor

$P / D$ - Pleurectomy/Decortication

PFS - Progression free survival

PI3K - Phosphatidylinositol 3-kinase

PR - Partial response

RNA - Ribonucleic acid

SRC - Sarcoma

SD - Stable disease 
TGF-alpha - Tumor growth factor alpha

TKI - Tyrosine kinase inhibitor

VEGF - Vascular endothelial growth factor

VEGFR - Vascular endothelial growth factor receptor 


\section{Introduction}

Malignant mesothelioma (MM) is a rare malignancy, most commonly located to the pleura (malignant pleural mesothelioma (MPM)) (90\%) or peritoneum (less than 10\%). Around $75 \%$ of patients have been exposed to asbestos with a latency period around 20-40 years. Adverse prognostic factors are nonepithelioid histological subtype, advanced stage, poor performance status, low hemoglobin level, leucocytosis and thrombocytosis[1]. Patients with sarcomatoid and mixed histology tend to die within 10-12 months of diagnosis, whereas those with epithelioid histology tend to survive a few months longer[2]. Multimodality treatment including radiation therapy, surgery and chemotherapy is an option for some MPM patients with limited disease extension. Although MM has a low tendency to metastasize, MM grows highly invasive into surrounding tissue. The invasive growth is related to high levels of expression of matrix metalloproteinases that are able to degrade both basement membrane and stromal extracellular matrix components[3]. A systemic treatment is the main therapeutic option for most patients due to the invasive behavior and limited efficacy of radiation therapy.

Most experience on medical treatment of MM originates from trials on MPM. Current treatment of MPM includes chemotherapy with response rates around 20 to $40 \%$, progression free survival (PFS) from 5.3 to 8.9 months and median overall survival (OS) between 9-15 months in chemotherapy naïve patients[4]. The most active $1^{\text {st }}$ line regimens are platinum compounds together with another active agent such as pemetrexed, raltitrexed, gemcitabine, or vinorelbine. A much used combination of cisplatin and pemetrexed has yielded response rates (RR) of $41.3 \%$, median OS of 12.1 months and median PFS of 5.7 months in a randomized trial[5].

Most patients with MPM progress during or shortly after $1^{\text {st }}$ line treatment and $2^{\text {nd }}$ line treatments are frequently used in this setting. There is no standard $2^{\text {nd }}$ line treatment in MPM although pemetrexed has been suggested to pemetrexed naïve patients due to studies reporting RR of 5.5 to $32.5 \%$, PFS of 3.8 to 7.4 months and OS of 4.1 to 9.8 months Various second line chemotherapy regimens in pemetrexed pretreated patients has yielded RR of 7 to $11 \%$, PFS of 2.2 to 3.5 months and median OS of 5.9 to 10.9 months[6]. Due to the limited efficacy of chemotherapy new treatment options are clearly warranted and several targeted agents have thus been explored. Accordingly, we reviewed the current status of targeted treatment in MM. 


\section{Materials and methods}

An extensive literature search was performed in January 2011 using pubmed and medline. Articles using targeted agents in malignant mesothelioma and providing clinical details, patient characteristics, treatment and outcome qualified for inclusion in the review. Keywords used were combinations of, "mesothelioma","targeted treatment","biological treatment","molecular targets" and "tyrosine kinase inhibitor" Reference lists in relevant articles were also used. ASCO abstracts from 2009 and 2011 were included as it was assumed that earlier abstracts have been published. In the case of phase I trials only data relevant for malignant mesothelioma have been mentioned. Full tables of all clinical trials discovered are displayed. Data on ongoing trials were derived from www.clinicaltrials.gov.

\section{Results}

Drugs have been listed according to their target. As for multikinase inhibitors the drug has been listed according the most relevant target.

\section{Platelet derived growth factor/ Platelet derived growth factor receptor (PDGF/PDGFR) (Table 1)}

PDGF (platelet derived growth factor receptor) is a growth factor inducing mesothelial cell proliferation. The PDGF-alpha receptor is known to be overexpressed on mesothelioma cells. Increased secretion of PDGF is thought to cause the thrombocytemia, which is known to be an adverse prognostic factor, occurring in many patients with MM[7]. Indeed high serum PDGF in MPM patients seems to be an independent predictor of poor survival[8]. Overexpression of PDGF-alpha has been shown in MM cell lines and blocking of the PDGFR has led to growth inhibition in vitro[3]. This combined with the fact that expression of c-Kit is seen in $26 \%[9]$ of MM patients spurred clinical trials investigating imatinib in MM. Imatinib is a selective tyrosine kinase inhibitor (TKI) of the bcr/abl mutated tyrosine kinase as well as c-kit and the PDGFR. Four phase II clinical trials of imatinib as a single agent in MM have been published. A total of 94 patients were included in these four trials without responders[10-13]. A trial by Mathy et al. included 25 patients reported a median OS of a whole 398 days. For 3 patients there was a stabilization of disease (SD) for longer than 6 months[11]. Porta et al. treated 11 MPM patients. The trial included both chemotherapy naïve as well as pretreated patients. No responders were seen but $4(36.4 \%)$ patients obtained SD. The remaining 7 (63.6\%) patients had progression of disease (PD). OS was 20 week with a fairly better survival in patients with SD (29.5 vs. 14 weeks)[12]. In a trial by Millward et al. 29 MPM patients were included. Best response was SD in 11 patients of which 4 patients had SD in more than 4 months and 1 patient had reduction in pleural thickness by $25 \%[10]$. These results have not warranted further studies of imatinib as a single agent in MM. In vitro and in vivo experiments have indicated that imatinib may enhance the chemotherapy sensitivity to gemcitabine and pemetrexed in MPM [14]. PDGFR is a mediator of interstitial fluid pressure (IFP). Thus the inhibition of PDGFR with imatinib with paclitaxel has been shown to lower the IFP with a possible subsequent 
improvement in drug delivery and increased efficacy in vitro [15]. One phase I trial with imatinib in combination with gemcitabine included 5 patients with MM. One patient had partial response (PR) [16]. A phase I trial investigating imatinib in combination with pemetrexed and cisplatin[17]. Similarly a phase II trial evaluating imatinib in combination with gemcitabine is being planned. Primary endpoint will be overall RR and secondary endpoints will be PFS, OS and safety[18].

Dasatinib is an inhibitor of the Src family of nonreceptor tyrosine kinases and PDGFR. Preclinical trials have shown that dasatinib has cytotoxic effects and leads to decreased migration and invasion in mesothelima cell lines[19]. A trial by Tsao et al. used dasatanib as neoadjuvant treatment in operable MPM patients. Primary endpoint was evaluation of Src (Tyr419) as a predictive biomarker. 15 enrolled patients received 4 weeks of preoperative dasatinib treatment followed by pleurectomy/decortication $(P / D)$ in 10 patients and extrapleural pneumonectomy (EPP) in 5 patients. Responding patients received 2 years of dasatinib maintenance after postoperative adjuvant radiotherapy and chemotherapy was given. Preliminary data showed that 1 out of 15 enrolled patients had minor response, 12 patients had PD after 4 weeks of treatment [20]. Another phase II trial was conducted in 46 inoperable patients with no responders and PFS and median OS of 2.0 months and 4.8 months, respectively [21]. Currently an ongoing phase II study evaluates dasatinib in previously treated MM patients [22].

Sorafenib is an inhibitor of VEGFR-2 and PDGFR-beta. Two phase II trials including a total of $70 \mathrm{MM}$ patients showed modest RR of $4 \%$ and $8 \%[23,24]$. A trial by Janne et al. including 51 patients included both chemotherapy naïve patients and patients previously treated with chemotherapy. SD was seen in $28(60 \%)$ patients and median OS was 10.7 months. PFS was 3.7 months and 3 months PFS was $78 \%$. The PFS were 3.6 and 3.6 months and the median OS were 4.9 months and 14.6 months in chemo naïve and previously treated patients, respectively. The improved clinical outcome in previously treated patients most likely reflects patient selection [24]. In the trial by Irshad et al. 19 MM patients were included. The study, which is still ongoing, also evaluates changes in FDG-PET activity as a measure of response. 1 PR was observed and 13 patients obtained SD as best result, of which $5(31 \%)$ remained progression free at 24 weeks[23].

Sunitinib is a multi-targeted TKI that blocks the tyrosine kinase activities of VEGFR-2, PDGFR-beta and c-Kit. One trial by Nowak et al. reported preliminary data of sunitinib in MPM as 2nd line treatment after $1^{\text {st }}$ line treatment with platinum and antimetabolite (pemetrexed/gemcitabine). Primary endpoint is safety and efficacy. Modified recist criteria or metabolic response on FDG-PET in patients without prior talc pleurodesis is used for response evaluation. The RR was $10 \%$ and median OS was 6.7 months among the 53 enrolled MPM patients. SD was seen in $33(66 \%)$ patients [25]. 


\section{Epithelial growth factor receptor (EGFR) (Table 1)}

The epithelial growth factor receptor (EGFR) plays a role in cell proliferation, differentiation, migration, adhesion and survival [26]. Tyrosine kinase EGFR is overexpressed both at protein and transcriptional level in more than $50 \%$ of MPM patients[27]. Overexpression of EGRF seems to predict favorable prognosis probably because of greater EGRF expression in the epitheliod cell type compared to the sarcomatoid cell type [26].

Two phase II trials in $1^{\text {st }}$ line treatment with the EGFR TKI gefitinib in MPM have been conducted. Among 63 patients included in the two clinical trials $2 \mathrm{PR}$ and 1 complete response (CR) were seen [28,29](Table 1). The trial by Lee et al. included 21 MPM patients. PR was seen in 1 patient and SD was seen in 10 (50\%) patients. The reported median OS of 14.1 months likely reflect patient selection, and possibly the effect of chemotherapy as salvage therapy [29]. Govindan et al. included 43 chemotherapy naïve MM patients. 97\% of the enrolled patients had EGFR overexpression. $1 \mathrm{CR}$ and $1 \mathrm{PR}$ were seen. Both responders had epitheloid subtype and CALGB prognostic group of 3.21 (49\%) patients had stable disease up to 24 weeks. Median PFS was 2.6 months and only $40 \%$ of patients remained progression free for at least 3 months. There were no difference in PFS when comparing patients with low EGFR and high EGFR expression. Patients with high EGFR expressing tumors had median OS of 8.1 months while patients with low EGFR expressing tumors had median OS of 3.6 months. Median OS of all patients were 6.8 months. Similarly patients with epitheloid tumor histology had median OS of 7.7 months while patients with non-epitheloid histology had median OS of 2.9 months. No difference in PFS was seen regarding histological subtype[28].

Erlotinib is another EGFR TKI. One phase II trial by Garland et al. investigated erlotinib in previously untreated MPM patients included 63 patients. No objective responses were seen. SD was seen in $42 \%$ of patients and lasted at least 6 weeks. The median OS were 10 months. Analysis did not find any correlation between EGFR expression and SD. Erlotinib did not show any efficacy against MPM in spite of high expression of EGFR[30](Table 1). One trial with a combination of erlotinib and bevacizumab will be mentioned later[31](Table 2). One reason for the low efficacy of EGFR inhibitors in spite of over expression of the receptor might be that mutations in EGFR are rare in MM[32]

\section{VEGF/VEGFR (Table 1 and 2)}

Vascular endothelial growth factor (VEGF) is an autocrine growth factor leading to angiogenesis through the binding of endothelial cell receptors. Preclinical studies have shown that VEGF and VEGFR are highly expressed in MPM. Moreover VEGF levels in MM patients are higher than in healthy individuals or in patients with other malignancies[33]. A high level of VEGF is positively correlated with microvascular density and is associated with a poor prognosis [34] and it has been observed that VEGF levels increase with more advanced disease stages in MPM [35]. VEGF stimulates MPM cells in a dose related manner and the growth of MPM cell has shown to be inhibited by anti-VEGF antibodies [36]. 
Bevacizumab is a monoclonal antibody targeting VEGF. A phase II trial by Jackman et al. combined erlotinib and bevacizumab to obtain a dual inhibition of EGFR and VEGFR. The trial included 24 patients did not result in any responders. 12 patients (50\%) had SD for at least 2 cycles. The median PFS was 2.2 months and median OS 5.8 months. 8 patients required dose reduction and 2 patients discontinued treatment due to toxicities e.g. rash, diarrhea, and dysphagia[31](Table 2).

Another randomized phase II trial by Kindler et al. compared cisplatin and gemcitabine with or without bevacizumab. 115 inoperable chemotherapy naïve patients were included. The treatment was well tolerated but no improved clinical benefit was observed in the bevacizumab arm. Response rates were $25 \%$ and $22 \%$ and median OS were 15.6 and14.7 months, respectively. A subset analysis suggested longer survival in patients with low circulating levels of VEGF[37].

Radaideh et al combined treatment with cisplatin and pemetrexed with bevacizumab in a phase II trial. The trial included 45 inoperable chemotherapy naïve MM patients. Primary endpoint the presented subanalysis was association between hypertension and clinical outcome. Preliminary results revealed a response rate of $41 \%$, median PFS of 6.9 months and median OS 15.3 months. Development of hypertension was reported as a possible surrogate marker for bevacizumab activity and was a significant predictor of outcome[38]. A two-armed phase II/III trial by Zalcman et al. compared an often used treatment with cisplatin and pemetrexed with or without bevacizumab as first line treatment in inoperable MPM patients. A preliminary analysis of the study revealed that the response rate in the cisplatin-pemetrexed-bevacizumab arm was mere $14.4 \%$. Patients with disease control (CR+PR+SD) at 6 months were statistically significant at $73.5 \%$ and $43.2 \%(p=0.010)$ respectively, in favor of the bevacizumab arm. The treatment was well tolerated[39](Table 2).

Vatalanib is an inhibitor of all VEGFRs. One phase II trial by Jahan et al evaluated valatanib in previously untreated patients. The trial did not achieve the protocol-specified 3 months PFS of $75 \%$. But it yielded a RR of $11 \%$ and a PFS of 4.1 months. Median OS was 10 months. There was no correlation between baseline VEGF or PDGF levels and response, PFS, or survival[40](Table 1).

Cediranib is a potent pan-VEGFR inhibitor that has antitumor activity in several solid tumors[41-43]. One phase II trial by Garland et al. included 54 patients with MPM who had received prior treatment with platinum based chemotherapy. Preliminary results showed a PR in $9 \%$ of patients, median PFS of 2 months and median OS of 10 months. 15 patients (33\%) had SD[44](Table 1). This trial has led to the initiation of a combined phase I and randomized phase II trial comparing cisplatin and pemetrexed with or without cediranib in chemotherapy naïve MPM patients. Primary outcomes are the maximal tolerated dose of cediranib and safety/toxicity and PFS[45].

Semaxanib is an inhibitor of the VEGF-1 receptor and, less potently, PDGFR and c-Kit. One phase II trial included 9 pretreated patients resulted in PR in 1 patient[46]. Semaxanib is no longer produced after reports of severe side effects e.g. excessive risk of thrombosis. Moreover as the oral bioavailability of semaxanib is low it requires intravenous administration [47](Table 1). 
Thalidomide inhibits angiogenesis through inhibition of VEGF, basic fibroblast growth factor and Tumor growth factor alpha (TGF-alpha). A phase I trial by Baas et al. was conducted with thalidomide in 40 MPM patients with $33 \%$ of patients being chemotherapy naïve. There were no responders and OS was 7.6 months. Eleven (27.5\%) were free of progression after 6 months [48]. Two parallel phase II studies by Pavlakis et al. evaluated thalidomide in combination with gemcitabine/cisplatin or thalidomide as a single agent. 27 patients who had received prior chemotherapy or were unsuitable for chemotherapy were treated with single agent thalidomide. Responses occurred in $6 \%$ of patients and OS was 11 months. 31 chemotherapy naïve patients received thalidomide and gemcitabine/cisplatin in another trial. Partial responses occurred in $14 \%$ and OS was 11 months[49](Table 2). The currently ongoing NVALT phase III trial includes patients who have not progressed after first line treatment. Patients must have received 4 to 6 cycles of pemetrexed with or without platinum and are randomized to receive either no treatment or thalidomide $100 \mathrm{mg}$ nightly increasing to 200 after 2 weeks. Treatment with thalidomide will continue up to 1 year. The main objective is whether the treatment with thalidomide will lead to increased PFS [34,50].

\section{PI3K/AKT/mTOR pathway (Table 3)}

Rapamycin (sirolimus) is a natural macrolide, produced by streptomyces hygroscopicus, which has antifungal and immunosuppressant activities Sirolimus is approved as an immunosuppressant used especially in kidney transplants. Sirolimus has an antiproliferative effect on the PI3K/AKT/mTOR pathway through the tyrosine kinase mTOR (mammalian target of rapamycin). The PI3K and AKT are often hyperactivated in human cancers and leads to cancer cell growth and invasiveness. The PI3K/AKT/mTOR pathway is often aberrant in MPM and in vitro studies have shown that inhibition of the pathway may induce apoptosis in MPM cell lines[51,52]. The derivate of rapamycin - temsirolimus - has been evaluated in a phase I trial including $2 \mathrm{MM}$ patients. None responded to the treatment[53]. One in vitro study showed synergistic antitumor effect against MPM cell lines of a combination of cisplatin and sirolimus [54]. One in vitro study indicates that sirolomus and cisplatin in combination increases the cytotoxic effect compared to either drug alone[54]. Everolimus (RAD001) is an orally administered mTOR inhibitor is currently being evaluated in 2 phase II trials planned to enroll 39 and 55 pretreated patients, respectively $[55,56]$. 


\section{Mesothelin (Table 3)}

MORAB-009 is monoclonal antibody targeting mesothelin. Mesothelin is highly expressed in several cancers, including MM, ovarian cancer, pancreatic cancer and some squamous cell carcinomas. Mesothelin is highly expressed in almost all MM of the epithelioid subtype, but not in the sarcomatoid or in the epithelial cells of the biphasic subtype[57-59]. The high membrane expression of mesothelin in MM and the limited distribution of mesothelin in normal tissues raised interest for mesothelin as an antitumor target[60]. Two phase I trials have been conducted including 23 patients. No responders were encountered among MM patients[61,62]. Currently an open label trial is being conducted treating MPM patients with MORAB-009 in combination with pemetrexed and cisplatin. Primary endpoints are efficacy and safety[63].

\section{Ribonuclease (Table 3)}

Ranpirnase is a ribonuclease that breaks down RNA. This irreparable RNA damage may constitute a death signal for apoptosis and also contributes to the inhibition of the cell growth and proliferation. Ranpirnase has been tested in one phase II trial with 105 mesothelioma patients with $67 \%$ being chemotherapy naïve. RR was $4.9 \%$ and OS 6 months. $15.2 \%$ of patients were removed from the study due to adverse effects e.g. renal insufficiency, allergic reaction, arthalgia and peripheral edema[64]. A phase III trial compared ranpirnase plus doxorubicine versus single agent doxorubicine. Ranpirnase plus doxorubicin did not improve OS. A preplanned analysis including 130 pretreated patients showed significant survival advantage in favor of ranpirnase plus doxorubicin with mean survivals of 10.5 versus 9.0 months, respectively[65].

\section{Asparagine-Glycine-Arginine-Human Tumor Necrosis Factor alpha (NGR-hTNF) (Table 3)}

Tumor necrosis factor alpha (TNF-alpha) has antitumor activity through activation of apoptosis. However treatment with NGR-hTNF has severe toxicities which only allow tumor necrosis factor to be administered in doses that are at least 10 fold lower than the effective dose in preclinical models[66-68]. NGR-hTNF consists of human TNF-alpha fused to the tumor-homing peptide asparagine-glycine-arginine (NGR) able to selectively bind an aminopeptidase $\mathrm{N}$-isoform overexpressed on tumor blood vessels. A phase II trial by Gregorc included 57 patients evaluating NGR-hTNF. PR was seen in one (2\%) patient. 18 (31\%) Patients with SD had a median PFS of 4.4 months. Overall PFS and OS were 2.8 months and 12.1 months, respectively. The treatment was well tolerated[69]. This led to the initiation of a pivotal randomized doubleblinded phase III trial expected to enroll 400 MPM patients. Patients who are pretreated with pemetrexed and candidate to either supportive care alone or chemotherapy are randomized to NGR-hTNF plus best investigators choice $(B I C)$ versus placebo. BIC includes either supportive care or gemcitabine or vinorelbine[70]. 


\section{Histone deacetylase inhibitors (HDACi) (Table 3)}

Histone proteins exist in either acetylated or deacetylated configurations and the equilibrium between the two forms is regulated by histone acetyltransferase and histone deacetylase (HDAC). When deacetylated the histones bind to DNA which are thereby rendered transcriptionally inactive. Through this mechanism HDACi are very potent inducers of apoptosis[71]. Suberoylanilide hydroxamic acid (SAHA/vorinostat) has already shown activity in the treatment of cutaneus T-cell lymphoma[72].

In 2005 the first phase I trial concerning vorinostat in patients with MPM was published by Kelly et al[73]. Out 73 patients enrolled 13 patients had MPM. Only one MM patient was chemotherapy naïve. In 2 patients $(15 \%)$ initial radiographic response was seen, but this was later unconfirmed. Four patients (30\%) had SD. Dose limiting toxicities were anorexia, dehydration, diarrhea and fatigue. A phase I trial by Ramalingham et al. combined vorinostat with carboplatin and paclitaxel led to SD in the one included MPM patient[74]. These results have led to the initiation of a phase III trial planned to include 660 MPM patients who have progressed after treatment with pemetrexed and platinum. Patients are randomized 1:1 to receive vorinostat $300 \mathrm{mg}$ two times a day or placebo. Primary outcome will be OS and number of patients with grade $3 / 4$ adverse effects[75].

Ramalingham et al. evaluated another HDACi, Belinostat, in a phase II trial in 13 patients. There were no responders and PFS was only 1 month and OS was 5 months. Only two patients (15\%) had SD [76]. In vitro studies suggests increased efficacy of HDACi in combination with other agents[71].

In Vitro data suggests that valproic acid has proapoptotic effect, which was synergized with doxorubicine. This led to a phase II trial by Scherpeereel et al. that included 45 pretreated patients to treatment with valproic acid in combination with doxorubicine[77]. PR was seen in 7 patients (16\%), all with good initial performance status. Best disease control rate (PR+SD) was 36\% ( $\mathrm{Cl} 22-51 \%)$. Median response duration was 11.8 months. Median PFS and median OS were 2.5 months and 6.7 months, respectively.

\section{Newer drugs and targets under investigation}

Most cancer cells are dependent on the G2 checkpoint to survive this has led to the development of CBP501 which is a G2 checkpoint abrogator. One phase 1 trial by Geoffrey et al. included 3 patients, which were treated with CGP501 in combination with cisplatin[78]. One patient had PR and PFS of 9.7 months. Two patients had SD that lasted for 11 months and 3 months, respectively. A combined phase $1 / / 1$ trial is currently ongoing enrolling patients with solid tumors (phase I) and MPM patients (phase II). Patients will receive treatment with CBP501 in combination with pemetrexed and cispatin. MPM patients will be randomized to pemetrexed and cisplatin with or without CBP501. 
IMC-A12 is an antibody targeting the insulin-like growth factor 1 (IGF-1). Inhibition of IGF-1 receptor has lead to decreased cell proliferation and enhanced the cytotoxic effect of cisplatin in vitro [79]. A phase II study is evaluating IMC-A12 in MM is ongoing. It is planned to enroll 55 pretreated MM patients.

Pazopanib is an oral angiogenesis inhibitor targeting VEGFR, PDGFR and c-Kit. An ongoing phase II study is evaluating single agent pazopanib in MPM patients[80]. Similarly axitinib is a pan-VEGFR inhibitor also inhibiting PDGFR and c-Kit. Axitinib is currently being evaluated in a randomized combined phase $\mathrm{I} / \mathrm{II}$ trial where patients will be randomized to cisplatin and pemetrexed with or without axitinib[81].

Bortezomib is a potent inhibitor of the 20 s proteasome, which has shown to have cytotoxic effect in vitro, and in MM xenografts in vivo. [82] This has led to the initiation of a phase II trial planned to enroll 111 patients to receive treatment with single agent bortezomib[83]. Bortezomib has been shown to increase the cytotoxic effect of cisplatin and pemetrexed when dosed prior to either in MPM cell lines [84]. A phase II trial evaluating bortezomib in combination with cisplatin as 1st line treatment in MM patients is currently ongoing. Primary endpoint is PFS at 18 weeks. The trial are planned to enroll 76 patients. Patients will receive up 63 week cycles of cisplatin and bortezomib in the absence of PD or unacceptable toxicity[85].

Cetuximab, an antibody targeting EGFR are currently being evaluated in combination with cisplatin/carboplatin and pemetrexed as $1^{\text {st }}$ line treatment in MPM patients. Patients will be treated with standard chemotherapy (4-6 cycles), combined with weekly administration of Cetuximab until disease progression. The trial is planned to enroll 18 MPM patients[86].

Azatidine is a cytidine analogue, which is currently being tested in a phase I study in combination with thalidomide in patients with either soft tissue sarcoma or MM[87]. 


\section{Discussion}

The prognosis of MM is still poor and there is a need for more effective antineoplastic drugs. The better understanding of the biology of MPM has led to the assessment of a number of targeted agents. Targeted treatments have been explored in several other cancer types and might be beneficial in the treatment of some, e.g. bevacizumab in non small cell lung cancer (NSCLC) $[88,89]$ and in other malignancies such as breast cancer, glioblastoma, colon cancer, and ovarian cancer[90-93]. Another example is gefitinib in chemotherapy naïve NSCLC patients harboring EGFR mutations[94].

There are several challenges concerning clinical trials of targeted malignant mesothelioma, which is reflected in the somewhat suboptimal design in some clinical designs described in this review. The double blinded randomized clinical trial remains the 'gold standard' of clinical trial design, but is hampered by the relative rarity of this disease. Of importance of the clinical trials are clear definition of the study populations, endpoints, sample sizes, power calculations, treatment allocations and stratifications[95]. The accrual and stratification of mesothelioma patients may cause potential problems especially in $1^{\text {st }}$ line experimental treatments due to the fact that chemotherapy naïve MM patients are currently usually receiving platinum-based doublet chemotherapy often with pemetrexed. Hence, most chemotherapy naïve MM patients included in recent clinical trials with targeted treatment have not been fit to receive such standard chemotherapy. A trial including mainly patients with poor performance status may negatively influence the outcome observed in the clinical trials with targeted agents in $1^{\text {st }}$ line treatment.

It is also important to include enough patients to make firm conclusions on efficacy. The sample size obviously depends on the endpoint selected and also the expected grade of difference between treatment arms. Stratification based on biomarker status could be considered. Populations harboring specific biomarkers may make it possible to reduce the needed sample size, but it will not be possible to generalize the results due to lack of reliable biomarkers and unknown off-target effects.

Stratification based on biomarkers has been successful in the case of imatinib in the treatment of chronic myeloid leukemia and gastro-intestinal stromal tumors (GIST). CML and which often harbor activating mutations in BCR-ABL, and GIST which often has activating mutations in c-Kit[96]. Imatinib entered clinical trials in mesothelioma due to the effect on c-Kit, which is expressed in about $26 \%$ of MM patients [9]. However, expression of unmutated c-kit in MM may not predict efficacy of imatinib[97]. Stratification based on biomarker status in future MM trials seems warranted.

Phase II trials are most commonly used to evaluate anti-tumor efficacy using objective response as the surrogate endpoint for patient benefit. But it is not possible to directly translate response to an improved PFS or OS, which especially gives rise to difficulties when evaluating targeted drugs for which SD is the main criterion of efficacy. Also it is challenging to compare objective response between different clinical trials due to the fact that response evaluation is inherently difficult in MPM because of the growth along the pleural surface causing problems when measuring the longest uni-dimensional diameter of the target mass. To solve this problem, Nowak et al. suggested modified RECIST criteria measuring tumor size perpendicular to 
the thoracic wall or mediastinum instead of longest diameter to produce more accurate and objective response evaluations[98]. However, a notably interobserver variability is still observed. Another solution could be the use of PET-CT, which is a promising evaluation modality in all stages of MPM including evaluation of treatment response[99] but it still needs further evaluation.

OS is another common endpoint in, which is defined as the time from randomization to the time of death[100]. OS is an accurate endpoint, which can be evaluated easily and precisely and evaluation of OS is not subject to predetermined intervals. Furthermore, the evaluation of OS includes the entire intention to treat population instead of only evaluating subset groups. Although OS is a precise endpoint it is influenced by patient and tumor characteristics, comorbidity and stage, thus hampering comparison between trials. Another obstacle when comparing $\mathrm{OS}$ is the number and types of previous and subsequent treatments after progression. Especially with newer and more efficient drugs, OS may require longer follow up periods, which leads to the risk of patients being lost to follow up. Furthermore, to reveal significant difference in OS between treatment arms, large patient populations are required.

PFS is the duration of time from randomization to tumor progression or death of any cause. PFS is thus not sensitive to subsequent drug treatment as the progression event has already occurred before initiation of subsequent treatment. The events occurs earlier when using PFS than OS making it possible to collect and analyze PFS data earlier and also fewer patients may be required to show a statistical difference between treatment arms[101]. PFS seeming a suitable endpoint for evaluating targeted drugs. Another alternative is PFS rate at $3,4,5$ or 6 months, which are easily obtainable endpoints as the event is a rate at predefined time[102].

The design problems of phase II trials give rise to challenges when evaluating whether a potential drug candidate should proceed to a randomized phase III trial while phase III trials make it is possible to evaluate OS benefit or improvements in PFS they are also expensive and may carry ethical problems if the preceding phase II trial has not shown promising efficacy of the drug. In some cases it may be possible to go directly from phase I testing to phase III testing if the drug has shown great potential in the phase I setting as seen in the case of vorinostat.

Drugs explored in $1^{\text {st }}$ line include the tyrosine kinase inhibitors dasatanib, vatalanib, gefitinib and erlotinib that have all been explored in chemotherapy naïve MM patients. None showed RR exceeding $12 \%$ or PFS above 4.1 months. Median OS varies widely from 5.0 to 13.1 months. Gefitinib was used in two $1^{\text {st }}$ line trials with low RR of $4 \%$ and $5 \%$ and median OS of 6.8 and 14.1 months, respectively[20,27,30,103]. Despite low RR and short PFS some studies present median OS above 10 months which compares to current $1^{\text {st }}$ line chemotherapy of MPM[4]. The trials exploring TKI are all phase II trials with limited number of patients and activity of these drugs is not firmly established. In contrast the addition of the VEGFR inhibitor bevacizumab to chemotherapy with pemetrexed and cisplatin in a randomized phase II/III trial was significantly superior to the same chemotherapy without bevacizumab with regard to response and disease stabilization[39]. A similar randomized phase II trial did not find significant clinical benefit of the addition of bevacizumab to gemcitabine and cisplatin[37]. Addition of bevacizumab to standard treatment for MM merits further evaluation. 
Drugs explored in $2^{\text {nd }}$ line and above include Sorafenib, imatinib and cediranib, which have all been, explored both in trials that included both chemotherapy naïve patients and previously treated patients. None showed RR higher than $9 \%$ or PFS longer than 3.7 months in $2^{\text {nd }}$ line or above. As for OS there were wide variations. Imatinib in combination with gemcitabine also failed to produce responders. Bevacizumab in combination with erlotinib did not produce any responders but OS was 5.8 months. $2^{\text {nd }}$ line Thalidomide yielded OS of 11 months, which may merit further examination. Overall, targeted treatments alone in $2^{\text {nd }}$ line treatment of MM does not currently induce better clinical outcomes than hitherto reported chemotherapy regimens which revealed RR of 5.5 to $32.5 \%$, PFS of 2.2 to 7.4 months and OS of 4.1 to 10.9 months[6]. Several trials report stabilization of disease in a number of patients. Coupled with the fact that several of the targeted drugs in vitro seems to enhance the cytotoxic effect of classic chemotherapy, targeted drugs may theoretically provide clinical benefit in combination therapies which should be explored. Furthermore, the efficacy seen in some patients might represent undefined subgroups that will benefit from treatment. Search for predictive markers to define potential subgroups should be urged as targeted treatment may likely be inefficient when treating unselected groups of patients. Research in tumor biology continues to discover promising targets, which could be explored in MM, e.g. the EML4-ALK inhibitor, crizotinib that produced very promising results in the treatment of NSCLC pending activating mutations [104]. It remains unknown whether the histological subtype of MM or expression of tumor markers exhibits is important when selecting targeted treatments. Though a trial by Govindan et al. evaluating gefitinib suggested an improved OS for a subgroup having high EGFR expression and epitheloid subtype[28]. It may also be speculated that some targeted drugs may be efficient when combined with conventional chemotherapy, such as in the case of bevacizumab. Targeted agents like gefitinib, erlotinib, bevacizumab, and in the future probably also crizotinib are currently used in the treatment of NSCLC but it seems that MM has different genetic properties as these agents are not similarly active in MM compared to NSCLC, e.g. EGFR mutations are rare in MM compared to NSCLC. Separate trials of potential biomarkers should be conducted in MM to further explore this field, which is necessary to improve clinical results in the future. 
Table 1 - Targeted treatment with tyrosine kinase inhibitors in non-resectable malignant mesothelioma patients.

\begin{tabular}{|c|c|c|c|c|c|c|c|c|c|}
\hline Author & Agent & $\begin{array}{l}\mathrm{Ph} \\
\text { ase }\end{array}$ & $\begin{array}{l}\text { Primary } \\
\text { tumor }\end{array}$ & Histology & $\begin{array}{l}\text { Previous } \\
\text { systemic } \\
\text { treatments }\end{array}$ & $\begin{array}{l}\text { No. } \\
\text { of } \\
\text { pts. }\end{array}$ & $\begin{array}{l}\text { Res. } \\
(\%)\end{array}$ & $\begin{array}{l}\text { mPFS } \\
\text { (months) }\end{array}$ & $\begin{array}{l}\mathrm{mOS} \\
\text { (months) }\end{array}$ \\
\hline \multicolumn{10}{|c|}{ Drugs targeting PDGFR } \\
\hline $\begin{array}{l}\text { Villano } \\
\text { et al. } \\
2004 \text { [13] }\end{array}$ & Imatinib & II & $\begin{array}{l}\text { Pleura } \\
(94 \%), \\
\text { Periton } \\
(6 \%)\end{array}$ & $\begin{array}{l}\text { E (80\%) } \\
B(20 \%)\end{array}$ & $\begin{array}{l}\text { Prior chemo } \\
(n=16)\end{array}$ & 17 & $0 \%$ & 1.7 & NA \\
\hline $\begin{array}{l}\text { Porta } \\
\text { et al. } \\
2007 \text { [12] }\end{array}$ & Imatinib & II & NA & $\begin{array}{l}\text { E (72.2\%) } \\
\text { S (0\%) } \\
\text { B (27.2\%) }\end{array}$ & $\begin{array}{l}\text { None }(22.2 \%) \\
\text { Other }(81.8 \%)\end{array}$ & 11 & $0 \%$ & 2 & 5 \\
\hline $\begin{array}{l}\text { Mathy } \\
\text { et al. } \\
2005 \text { [11] }\end{array}$ & Imatinib & II & $\begin{array}{l}\text { Pleura } \\
(92 \%) \\
\text { Periton } \\
(8 \%)\end{array}$ & $\begin{array}{l}\text { E (80\%), } \\
\text { S (4\%) } \\
\text { B (12\%) } \\
\text { N/A (4\%) }\end{array}$ & $\begin{array}{l}\text { None }(n=23) \\
\text { Suramin }(n=1) \\
\text { Thal }(n=1)\end{array}$ & 25 & $0 \%$ & NA & 13.2 \\
\hline $\begin{array}{l}\text { Millward } \\
2003 \text { [10] }\end{array}$ & Imatinib & II & NA & NA & $\begin{array}{l}\text { Prior chemo } \\
(n=7) \\
\text { Cis/Carbo }(n=6) \\
\text { Gem }(n=4) \\
\text { Pem }(n=2) \\
\text { Vnb }(n=2)\end{array}$ & 29 & $0 \%$ & NA & NA \\
\hline $\begin{array}{l}\text { Yaqoob } \\
2007 \\
{[16]}\end{array}$ & $\begin{array}{l}\text { Imatinib + } \\
\text { Gem }\end{array}$ & 1 & NA & NA & NA & 5 & $20 \%$ & NA & NA \\
\hline $\begin{array}{l}\text { Tsao } \\
2010 \\
{[20]}\end{array}$ & Dasatinib & $\left({ }^{* *}\right)$ & NA & $\begin{array}{l}\text { E (87\%), } \\
\text { B (13\%) }\end{array}$ & None & 15 & $0 \%$ & $\mathrm{NA}$ & NA \\
\hline $\begin{array}{l}\text { Dudek } \\
2007 \\
{[21]}\end{array}$ & Dasatanib & II & $\begin{array}{l}\text { Pleural } \\
(76 \%)\end{array}$ & $E(72 \%)$ & Pem $100 \%$ & 46 & $0 \%$ & 2 & 4,8 \\
\hline $\begin{array}{l}\text { Janne } \\
2007 \text { [24] }\end{array}$ & Sorafenib & II & $\begin{array}{l}\text { Pleural } \\
(90 \%) \\
\text { Peritone } \\
\text { al }(10 \%)\end{array}$ & $\begin{array}{l}\text { E (37\%), } \\
\text { S (4\%) } \\
\text { B (8\%) } \\
\text { N/A }(2 \%)\end{array}$ & $\begin{array}{l}\text { None }(n=20) \text { or } \\
\text { Pem }(n=31)\end{array}$ & 51 & $4 \%$ & 3.7 & 10.7 \\
\hline $\begin{array}{l}\text { Irshad } \\
2010 \\
{[23]}\end{array}$ & Sorafenib & II & NA & NA & Platin $100 \%$ & 19 & $8 \%$ & NA & NA \\
\hline $\begin{array}{l}\text { Nowak } \\
2010[25]\end{array}$ & Sunitinib & II & $\begin{array}{l}\text { Pleura } \\
(100 \%)\end{array}$ & $\begin{array}{l}\text { E (70\%) } \\
\text { S (2\%) } \\
\text { B }(17 \%) \\
\text { NA }(11 \%)\end{array}$ & $\begin{array}{l}\text { Platin/Pem } \\
(79 \%) \\
\text { Platin/Gem } \\
(21 \%)\end{array}$ & 53 & $10 \%$ & $\mathrm{NA}$ & 6,7 \\
\hline \multicolumn{10}{|c|}{ Drugs targeting EGFR } \\
\hline $\begin{array}{l}\text { Govindan } \\
2005 \text { [28] }\end{array}$ & Gefitinib & II & $\begin{array}{l}\text { Pleura } \\
(98 \%), \\
\text { Periton } \\
(2 \%) \\
\end{array}$ & $\begin{array}{l}\text { E }(79 \%) \\
\text { S }(7 \%) \\
\text { B }(12 \%) \\
\text { NA }(2 \%)\end{array}$ & None & 43 & $4 \%$ & 2.6 & 6.8 \\
\hline $\begin{array}{l}\text { Anderson } \\
2008 \text { [29] }\end{array}$ & Gefitinib & II & $\begin{array}{l}\text { Pleura } \\
(100 \%)\end{array}$ & NA & None & 20 & $5 \%$ & $\mathrm{NA}$ & 14.1 \\
\hline $\begin{array}{l}\text { Garland } \\
2007 \text { [30] }\end{array}$ & Erlotinib & II & $\begin{array}{l}\text { Pleura } \\
(100 \%)\end{array}$ & $\begin{array}{l}\text { E }(44 \%), \\
\text { S }(3 \%), \\
\text { B }(11 \%), \\
\text { NA }(41 \%)\end{array}$ & None & 63 & $0 \%$ & 2 & 10 \\
\hline \multicolumn{10}{|c|}{ Drugs targeting VEGFR } \\
\hline $\begin{array}{l}\text { Jahan } \\
2006 \\
{[40]}\end{array}$ & Vatalanib & II & $\begin{array}{l}\text { Pleura } \\
(87 \%) \\
\text { Periton } \\
(6 \%) \\
\text { Other } \\
6 \%\end{array}$ & $\begin{array}{l}\text { E (80\%), } \\
\text { S (11\%), } \\
\text { B (9\%) }\end{array}$ & None & 46 & $11 \%$ & 4.1 & 10 \\
\hline $\begin{array}{l}\text { Garland } \\
2009 \text { [44] }\end{array}$ & Cediranib & II & NA & NA & Platin (100\%) & 45 & $9 \%$ & $3\left(^{*}\right)$ & $10\left(^{*}\right)$ \\
\hline $\begin{array}{l}\text { Kindler } \\
2001 \text { [46] }\end{array}$ & Semaxanib & II & NA & NA & $\mathrm{N} / \mathrm{A}$ & 9 & $11 \%$ & $\mathrm{NA}$ & 12.4 \\
\hline
\end{tabular}

B-Biphasic, Carbo-Carboplatin, Cis-Cisplatin, E-Epithelial, Gem - Gemcitabine, mOS-Median overall survival, mPFSmedian progressionfree survival, Pem-Pemetrexed, RES-Response, S-Sarcomatoid, Thal-thalidomide, Vnb-Vinorelbine $\left({ }^{\star}\right)$ Estimated results. Final results are N/A

$\left({ }^{\star \star}\right)$ Neoadjuvant 
Table 2 - Drugs targeting vascular endothelial growth factor in non-resectable malignant mesothelioma patients.

\begin{tabular}{|c|c|c|c|c|c|c|c|c|c|}
\hline Author & Agent & $\begin{array}{l}\text { Pha } \\
\text { se }\end{array}$ & $\begin{array}{l}\text { Primary } \\
\text { tumor }\end{array}$ & Histology & $\begin{array}{l}\text { Previous } \\
\text { systemic } \\
\text { treatments }\end{array}$ & $\begin{array}{l}\text { No. } \\
\text { of } \\
\text { Pts. }\end{array}$ & Res. (\%) & $\begin{array}{l}\text { mPFS } \\
\text { (months) }\end{array}$ & $\begin{array}{l}\text { mOS } \\
\text { (months) }\end{array}$ \\
\hline \multicolumn{10}{|c|}{ Drugs targeting vascular endothelial growth factor (VEGF) } \\
\hline $\begin{array}{l}\text { Jackman } \\
2008 \text { [31] }\end{array}$ & Erlotinib + Bvz & II & $\begin{array}{l}\text { Pleura } \\
(100 \%)\end{array}$ & $\begin{array}{l}\text { E (67\%) } \\
\text { S (8\%) } \\
\text { B (25\%) }\end{array}$ & $\begin{array}{l}\text { Platin/Pem } \\
\text { (67\%), } \\
\text { Platin/Gem } \\
(12 \%), \\
\text { Pem/Gem (21\%) }\end{array}$ & 24 & $0 \%$ & 2.2 & 5.8 \\
\hline $\begin{array}{l}\text { Karrison } \\
2007 \text { [37] }\end{array}$ & $\begin{array}{l}\text { Gem+Cis+Bvz } \\
\text { vs. } \\
\text { gem+Cis }\end{array}$ & II & $\begin{array}{l}\text { Pleura } \\
(93 \% / 91 \\
\%)\end{array}$ & $\begin{array}{l}\mathrm{E} \\
(74 \% / 67 \%)\end{array}$ & None & 115 & $25 \% / 22 \%$ & $\begin{array}{l}6.9 / 6.0 \\
(p=0.88)\end{array}$ & $\begin{array}{l}15.6 / 14.7 \\
(p=0.91)\end{array}$ \\
\hline $\begin{array}{l}\text { Zalcman } \\
2010 \text { [39] }\end{array}$ & $\begin{array}{l}\text { Pem+Cis+Bvz } \\
\text { vs. } \\
\text { Pem+Cis }\end{array}$ & $\mathrm{II} / \mathrm{III}$ & $\begin{array}{l}\text { Pleura } \\
(100 \%)\end{array}$ & $\begin{array}{l}\text { E (81\%) } \\
\text { Other } \\
(19 \%)\end{array}$ & None & 111 & $\left({ }^{* \star}\right)$ & NA & NA \\
\hline $\begin{array}{l}\text { Dowell } \\
2009 \text { [38] }\end{array}$ & Pem+Cis+Bvz & II & $\begin{array}{l}\text { Pleura } \\
(85 \%) \\
\text { Periton } \\
(12 \%) \\
\text { Tvag } \\
(3 \%)\end{array}$ & $\begin{array}{l}\text { E (62\%) } \\
\text { S (15\%) } \\
\text { B (20\%) } \\
\text { NA }(2 \%)\end{array}$ & None & 45 & $41 \%\left(^{*}\right)$ & 6.9 & 15.3 \\
\hline $\begin{array}{l}\text { Pavlakis } \\
2003 \text { [49] } \\
\left({ }^{*}\right)\end{array}$ & Thal+Cis/Gem & II & NA & NA & None & 31 & $14 \%$ & NA & 11 \\
\hline $\begin{array}{l}\text { Pavlakis } \\
2003 \text { [49] } \\
\left.{ }^{\star}\right)\end{array}$ & Thal & II & NA & NA & NA & 27 & $6 \%$ & NA & 11 \\
\hline $\begin{array}{l}\text { Baas } \\
2005 \text { [48] }\end{array}$ & Thal & I & $\begin{array}{l}\text { Pleura } \\
(100 \%)\end{array}$ & $\begin{array}{l}\text { E (90\%), } \\
\text { Other (10) }\end{array}$ & $\begin{array}{l}\text { Prior chemo } \\
(33 \%)\end{array}$ & 40 & NA & NA & 7.6 \\
\hline
\end{tabular}

B- Biphasic, Bvz-Bevacizumab, , Cis-Cisplatin, E-Epithelial, Gem-Gemcitabine, mOS-Median overall survival, mPFS-Median progression free survival, Pem-Pemetrexed, RES-Response, S-Sarcomatoid Thal-Thalidomide, Tvag-Tunica vaginalis

$\left.{ }^{*}\right)$ Preliminary data presented at ASCO 2009 - final results are N/A

$\left.{ }^{* \star}\right) \mathrm{RR}=14.4 \%$ vs. N/A (25/34 patients (73.5\%) with disease control (1 CR, 15 PR, 9 stable disease) in bevacizumab arm vs. 16/37

$(43.2 \%)$ with disease control in non-bevacizumab arm $(p=0.010))$ 
Table 3 - Miscellaneous targeted treatments for non-resectable malignant mesothelioma patients.

\begin{tabular}{|c|c|c|c|c|c|c|c|c|c|}
\hline Author & Agent & $\begin{array}{l}\mathrm{Ph} \\
\text { as } \\
\mathrm{e}\end{array}$ & $\begin{array}{l}\text { Primary } \\
\text { tumor }\end{array}$ & Histology & $\begin{array}{l}\text { Previous } \\
\text { systemic } \\
\text { treatments }\end{array}$ & $\begin{array}{l}\text { No } \\
\text { of } \\
\text { pts }\end{array}$ & $\begin{array}{l}\text { RES } \\
(\%)\end{array}$ & $\begin{array}{l}\text { mPFS } \\
\text { (months) }\end{array}$ & $\begin{array}{l}\text { mOS } \\
\text { (months) }\end{array}$ \\
\hline \multicolumn{10}{|c|}{ Drugs targeting mesothelin } \\
\hline $\begin{array}{l}\text { Laheru } \\
2008[62]\end{array}$ & MORab-009 & $\mathrm{I}$ & NA & NA & NA & 13 & $0 \%$ & NA & NA \\
\hline $\begin{array}{l}\text { Hassan } \\
2010[61]\end{array}$ & MORab-009 & $\mathrm{I}$ & $\begin{array}{l}\text { Pleura } \\
(50 \%) \\
\text { Periton } \\
(50 \%)\end{array}$ & $E(100 \%)$ & NA & 8 & $0 \%$ & NA & NA \\
\hline \multicolumn{10}{|c|}{ Drugs targeting PI3K/AKT/mTOR pathway } \\
\hline $\begin{array}{l}\text { Raymond } \\
2004 \text { [53] }\end{array}$ & Temsirolimus & 1 & NA & NA & NA & 2 & $0 \%$ & NA & NA \\
\hline \multicolumn{10}{|c|}{ Drugs targeting RNA } \\
\hline $\begin{array}{l}\text { Stanislaw } \\
2001 \text { [64] }\end{array}$ & Ranpirnase & II & NA & $\begin{array}{l}\text { E (47.6\%) } \\
\text { Other } \\
(15.2 \%) \\
\text { NA (37.2\%) }\end{array}$ & $\begin{array}{l}\text { Prior chemo } \\
(37.1 \%)\end{array}$ & 105 & $4.9 \%$ & 3.4 & 6 \\
\hline $\begin{array}{l}\text { Reck } \\
2009 \text { [65] } \\
\left({ }^{* *}\right)\end{array}$ & $\begin{array}{l}\text { Ranpirnase+D } \\
\text { oxo vs. doxo }\end{array}$ & III & NA & NA & $\begin{array}{l}\text { Pem (54\%) } \\
\text { Other (46\%) }\end{array}$ & 413 & NA & NA & $\begin{array}{l}11.1 \text { vs. } \\
10.7\end{array}$ \\
\hline \multicolumn{10}{|c|}{ Tumor Necrosis Factor } \\
\hline $\begin{array}{l}\text { Gregorc } \\
2010 \text { [69] }\end{array}$ & NGR-hTNF & II & NA & $\begin{array}{l}\mathrm{E}(79 \%) \\
\text { Other (21) }\end{array}$ & $\begin{array}{l}\text { Platin/Pem } \\
(93 \%) \\
\text { Gem/Cis } \\
(7 \%)\end{array}$ & 57 & $2 \%$ & 2.8 & 12.1 \\
\hline \multicolumn{10}{|c|}{ Histone deacetylate inhibitors (HDACi) } \\
\hline $\begin{array}{l}\text { Kelly } \\
2005 \text { [73] }\end{array}$ & $\begin{array}{l}\text { SAHA } \\
\text { (Vorinostat) }\end{array}$ & 1 & NA & $\begin{array}{l}\text { E (70\%) } \\
\text { B }(23 \%) \\
\text { NA }(7 \%)\end{array}$ & $\begin{array}{l}\text { Prior chemo } \\
(92 \%)\end{array}$ & 13 & $0 \%$ & NA & NA \\
\hline $\begin{array}{l}\text { Scherpeer } \\
\text { eel } 2011\end{array}$ & $\begin{array}{l}\text { Valproic } \\
\text { acid+doxo }\end{array}$ & II & $\begin{array}{l}\text { Pleura } \\
(100 \%)\end{array}$ & $\begin{array}{l}\text { E (80\%) } \\
\text { NA }(20 \%)\end{array}$ & $\begin{array}{l}\text { Prior chemo } \\
(100 \%)\end{array}$ & 45 & $16 \%$ & 2.5 & 6.7 \\
\hline $\begin{array}{l}\text { Ramaling } \\
\text { am 2007 } \\
{[74]}\end{array}$ & $\begin{array}{l}\text { SAHA } \\
\text { (Vorinostat) }\end{array}$ & 1 & $\begin{array}{l}\text { Pleura } \\
(100 \%)\end{array}$ & NA & NA & 1 & $0 \%$ & NA & NA \\
\hline $\begin{array}{l}\text { Ramaling } \\
\text { am 2009 } \\
{[76]}\end{array}$ & $\begin{array}{l}\text { PXD101 } \\
\text { (Belinostat) }\end{array}$ & II & $\begin{array}{l}\text { Pleura } \\
(100 \%)\end{array}$ & $\begin{array}{l}\text { E (54\%), } \\
\text { S (8\%) } \\
\text { NA }(38 \%)\end{array}$ & $\begin{array}{l}\text { Cis/Pem } \\
(60 \%) \\
\text { Carbo/Pem } \\
(32 \%) \\
\text { Cis/Gem } \\
(8 \%)\end{array}$ & 13 & $0 \%$ & 1 & 5 \\
\hline
\end{tabular}

B-Biphasic, Cis-Cisplatin, Doxo-Doxorubicine, E-Epithalial, Gem-Gemcitabine, NGRhTNF- Asparagine-Glycine-ArginineHuman Tumor Necrosis Factor alpha, Pem-Pemetrexed, S-Sarcomatoid $\left(^{*}\right) 2$ parallel studies

$\left({ }^{\star *}\right)$ in a preplanned analysis including 130 pretreated patients a significant advantage in survival in favor of DOX + ranpirnase was found (MST: 10.5 vs $9 \mathrm{~ms}$; HR $1.49,95 \% \mathrm{Cl} 1.02-2.17$ ). 


\section{References}

1. Steele JPC, Klabatsa A, Fennell DA, Palläska A, Sheaff MT, Evans MT, et al. Prognostic factors in mesothelioma. Lung Cancer 2005;49 Suppl 1:S49-S52.

2. Yates DH, Corrin B, Stidolph PN, Browne K. Malignant mesothelioma in south east England: clinicopathological experience of 272 cases. Thorax 1997;52(6):507-512.

3. Vogelzang NJ, Porta C, Mutti L. New agents in the management of advanced mesothelioma. Semin Oncol 2005;32(3):336-350.

4. Sørensen JB, Frank H, Palshof T. Cisplatin and vinorelbine first-line chemotherapy in non-resectable malignant pleural mesothelioma. Br J Cancer 2008;99(1):44-50.

5. Vogelzang NJ, Rusthoven JJ, Symanowski J, Denham C, Kaukel E, Ruffie P, et al. Phase III study of pemetrexed in combination with cisplatin versus cisplatin alone in patients with malignant pleural mesothelioma. J Clin Oncol 2003;21(14):2636-2644.

6. Ceresoli GL, Zucali PA, Gianoncelli L, Lorenzi E, Santoro A. Second-line treatment for malignant pleural mesothelioma. Cancer Treat Rev 2010;36(1):24-32.

7. Edwards JG, Cox G, Andi A, Jones JL, Walker RA, Waller DA, et al. Angiogenesis is an independent prognostic factor in malignant mesothelioma. Br J Cancer 2001;85(6):863-868.

8. Filiberti R, Marroni P, Neri M, Ardizzoni A, Betta PG, Cafferata MA, et al. Serum PDGF-AB in pleural mesothelioma. Tumour Biol 2005;26(5):221-226.

9. Arber DA, Tamayo R, Weiss LM. Paraffin section detection of the c-kit gene product (CD117) in human tissues: value in the diagnosis of mast cell disorders. Hum Pathol 1998;29(5):498-504.

10. Millward M, Parnis F, Byrne M, Powell A, Dunleavey R, Lynch K, et al. Phase II trial of imatinib mesylate in patients with advanced pleural mesothelioma. Am J Clin Oncol 2003;22:912.

11. Mathy A, Baas P, Dalesio O, van Zandwijk N. Limited efficacy of imatinib mesylate in malignant mesothelioma: a phase II trial. Lung Cancer 2005;50(1):83-86.

12. Porta, Mutti, Tassi. Negative results of an Italian Group for Mesothelioma (G.I.Me.) pilot study of single-agent imatinib mesylate in malignant pleural mesothelioma. Cancer Chemother Pharmacol 2007;59(1):149-150.

13. Villano J, Husain A, Stadler M, Hanson L, Vogelzang N, Kindler H, et al. A Phase II trial of imatinib mesylate in patients (pts) with malignant mesothelioma (MM). J Clin Oncol 2004;22:14.

14. Bertino P, Porta C, Barbone D, Germano S, Busacca S, Pinato S, et al. Preliminary data suggestive of a novel translational approach to mesothelioma treatment: imatinib mesylate with gemcitabine or pemetrexed. Thorax 2007;62(8):690-695.

15. Pietras K, Rubin K, Sjöblom T, Buchdunger E, Sjöquist M, Heldin CH, et al. Inhibition of PDGF receptor signaling in tumor stroma enhances antitumor effect of chemotherapy. Cancer Res 2002;62(19):5476-5484.

16. Ali Y, Lin Y, Gharibo MM, Gounder MK, Stein MN, Lagattuta TF, et al. Phase I and pharmacokinetic study of imatinib mesylate (Gleevec) and gemcitabine in patients with refractory solid tumors. Clin Cancer Res 2007;13(19):5876-5882.

17. Cisplatin, Pemetrexed, and Imatinib Mesylate in Malignant Mesothelioma. www.clinicaltrials.gov

18. A Phase II Study of the Association of Glivec ${ }^{\circledR}$ Plus Gemzar® in Patients With Unresectable, Refractory, 
Malignant Mesothelioma. www.clinicaltrials.gov

19. Tsao AS, He D, Saigal B, Liu S, Lee JJ, Bakkannagari S, et al. Inhibition of c-Src expression and activation in malignant pleural mesothelioma tissues leads to apoptosis, cell cycle arrest, and decreased migration and invasion. Mol Cancer Ther 2007;6(7):1962-1972.

20. Tsao A, Mistuba I, Mehren J. Evaluation of Src Tyr419 as a predictive biomarker in a neoadjuvant trial using dasatinib in resectable malignant pleural mesothelioma. Am J Clin Oncol 2010;25:15.

21. Dudek A, Pang H, Kratzke A. A phase II study of dasatinib (D) in patients (pts) with previously treated malignant mesothelioma. Journal of the National Cancer Institute 2010;28:15.

22. Dasatinib in Treating Patients With Previously Treated Malignant Mesothelioma. www.clinicaltrials.gov

23. Irshad S, Popat S, Shah R. A phase II study of sorafenib in malignant mesothelioma with pharmacodynamic imaging using 18fdg-PET. Journal of the National Cancer Institute 2010;28:15.

24. Dubey S, Jänne PA, Krug L, Pang H, Wang X, Heinze R, et al. A phase II study of sorafenib in malignant mesothelioma: results of Cancer and Leukemia Group B 30307. J Thorac Oncol 2010;5(10):1655-1661.

25. Novak A, Millward M, Francis R. Final results of a phase II study of sunitinib as second-line therapy in malignant pleural mesothelioma. J Clin Oncol 2010;28:15.

26. Yarden Y. The EGFR family and its ligands in human cancer. signalling mechanisms and therapeutic opportunities. Eur J Cancer 2001;37 Suppl 4:S3-S8.

27. Destro A, Ceresoli G, Falleni M. EGFR overexpression in malignant pleural mesothelioma. An immunohistochemical and molecular study with clinicopathological correlations. Lung Cancer 2006;51:207-215.

28. Govindan R, Kratzke RA, Herndon JE, Niehans GA, Vollmer R, Watson D, et al. Gefitinib in patients with malignant mesothelioma: a phase II study by the Cancer and Leukemia Group B. Clin Cancer Res 2005;11(6):23002304.

29. Lee C, Anderson H, Martins H. A phase II trial of gefitinib in patients with malignant pleural mesothelioma (MPM). J Clin Oncol 2008;26:15.

30. Garland LL, Rankin C, Gandara DR, Rivkin SE, Scott KM, Nagle RB, et al. Phase II study of erlotinib in patients with malignant pleural mesothelioma: a Southwest Oncology Group Study. J Clin Oncol 2007;25(17):2406-2413.

31. Jackman DM, Kindler HL, Yeap BY, Fidias P, Salgia R, Lucca J, et al. Erlotinib plus bevacizumab in previously treated patients with malignant pleural mesothelioma. Cancer 2008;113(4):808-814.

32. Cortese J, Gowda A, Wali A, Eliason J, Pass H, Everson R, et al. Common EGFR mutations conferring sensitivity to gefitinib in lung adenocarcinoma are not prevalent in human malignantmesothelioma. Int J Cancer 2006;118(2):521 522 .

33. Ohta Y, Shridhar V, Bright RK, Kalemkerian GP, Du W, Carbone M, et al. VEGF and VEGF type C play an important role in angiogenesis and lymphangiogenesis in human malignant mesothelioma tumours. Br J Cancer 1999;81(1):54-61.

34. Dowell J, Kindler H. Antiangiogenic therapies for mesothelioma. Hematol Oncol Clin North Am 2005;19:11371145 .

35. Yasumitsu A, Tabata C, Tabata R, Hirayama N, Murakami A, Yamada S, et al. Clinical significance of serum vascular endothelial growth factor in malignant pleural mesothelioma. J Thorac Oncol 2010;5(4):479-483.

36. Strizzi L, Catalano A, Vianale G, Orecchia S, Casalini A, Tassi G, et al. Vascular endothelial growth factor is an autocrine growth factor in human malignant mesothelioma. J Pathol 2001;193(4):468-475. 
37. Karrison, Kindler, Gandara. S374 Final analysis of a multi-center, double-blind, placebo-controlled, randomized phase II trial of gemcitabine/cisplatin (GC) plus bevacizumab (B) or placebo (P) in patients with malignant mesothelioma. J Thorac Oncol 2007;2:8.

38. Dowell J, Gerber D, Dunphy F. Association of hypertension (HTN) and clinical outcome in a phase II trial of cisplatin $(\mathrm{C})$, pemetrexed $(\mathrm{P})$, and bevacizumab $(\mathrm{B})$ in patients (pts) with untreated malignant mesothelioma. J Clin Oncol 2010;28:15.

39. Zalcman G, Margery J, Scherpereel A. IFCT-GFPC-0701 MAPS trial, a multicenter randomized phase II/III trial of pemetrexed-cisplatin with or without bevacizumab in patients with malignant pleural mesothelioma. J Clin Oncol 2010;28:15.

40. Jahan T, Gu L, Wang X. Vatalanib (V) for patients with previously untreated advanced malignant mesothelioma (MM): a phase II study by the Cancer and Leukemia Group B (CALGB 30107). J Clin Oncol 2006;24(18):7081.

41. Mitchell CL, O'Connor JPB, Roberts C, Watson Y, Jackson A, Cheung S, et al. A two-part Phase II study of cediranib in patients with advanced solid tumours: the effect of food on single-dose pharmacokinetics and an evaluation of safety, efficacy and imaging pharmacodynamics. Cancer Chemother Pharmacol 2010;

42. Drevs J, Siegert P, Medinger M, Mross K, Strecker R, Zirrgiebel U, et al. Phase I clinical study of AZD2171, an oral vascular endothelial growth factor signaling inhibitor, in patients with advanced solid tumors. J Clin Oncol 2007;25(21):3045-3054.

43. Matulonis UA, Berlin S, Ivy P, Tyburski K, Krasner C, Zarwan C, et al. Cediranib, an oral inhibitor of vascular endothelial growth factor receptor kinases, is an active drug in recurrent epithelial ovarian, fallopian tube, and peritoneal cancer. J Clin Oncol 2009;27(33):5601-5606.

44. Garland L, Chansky K, Wosniak A. A phase II study of novel oral antiangiogenic agent AZD2171 (NSC-732208) in malignant pleural mesothelioma. J Clin Oncol 2009;27:15.

45. Pemetrexed Disodium and Cisplatin With or Without Cediranib Maleate in Treating Patients With Malignant Pleural Mesothelioma. http://www.clinicaltrials.gov

46. Kindler H, Vogelzang J, Chien. SU5416 in malignant mesothelioma: a University of Chicago consortium study. J Clin Oncol 2001;20:341.

47. Morabito A, De Maio E, Di Maio M, Normanno N, Perrone F. Tyrosine kinase inhibitors of vascular endothelial growth factor receptors in clinical trials: current status and future directions. Oncologist 2006;11(7):753-764.

48. Baas P, Boogerd W, Dalesio O, Haringhuizen A, Custers F, van Zandwijk N, et al. Thalidomide in patients with malignant pleural mesothelioma. Lung Cancer 2005;48(2):291-296.

49. Pavlakis N, Abraham R, Harvie R. Thalidomide alone or in combination with cisplatin/Gemcitabine in malignant pleural mesothelioma (MM); Interim results from two parallel non randomized phase II studies. Lung Cancer 2003;41(2):11.

50. MATES: Maintenance Thalidomide in Mesothelioma Patients. A phase III trial of anti-angiogenic agent Thalidomide in patients with malignant pleural mesothelioma after first line chemotherapy. Journal of the National Cancer Institute

51. Ramos-Nino ME, Testa JR, Altomare DA, Pass HI, Carbone M, Bocchetta M, et al. Cellular and molecular parameters of mesothelioma. J Cell Biochem 2006;98(4):723-734.

52. Altomare DA, You H, Xiao GH, Ramos-Nino ME, Skele KL, De Rienzo A, et al. Human and mouse mesotheliomas exhibit elevated AKT/PKB activity, which can be targeted pharmacologically to inhibit tumor cell growth. Oncogene 2005;24(40):6080-6089. 
53. Raymond E, Alexandre J, Faivre S, Vera K, Materman E, Boni J, et al. Safety and pharmacokinetics of escalated doses of weekly intravenous infusion of CCI-779, a novel mTOR inhibitor, in patients with cancer. J Clin Oncol 2004;22(12):2336-2347.

54. Hartman ML, Esposito JM, Yeap BY, Sugarbaker DJ. Combined treatment with cisplatin and sirolimus to enhance cell death in human mesothelioma. J Thorac Cardiovasc Surg 2010;139(5):1233-1240.

55. Everolimus (RAD001) for the Treatment of Malignant Pleural Mesothelioma With Merlin/NF2 Loss as a Biomarker to Predict Sensitivity. www.clinicaltrials.gov

56. Everolimus in Treating Patients With Pleural Malignant Mesothelioma That Cannot Be Removed By Surgery. www.clinicaltrials.gov

57. Chang K, Pai LH, Pass H, Pogrebniak HW, Tsao MS, Pastan I, et al. Monoclonal antibody K1 reacts with epithelial mesothelioma but not with lung adenocarcinoma. Am J Surg Pathol 1992;16(3):259-268.

58. Shaw DR, Muminova ZE, Strong TV. Mesothelin: a new target for immunotherapy. Clin Cancer Res 2004;10(24):8751; author reply 8752.

59. Chang K, Pastan I. Molecular cloning of mesothelin, a differentiation antigen present on mesothelium, mesotheliomas, and ovarian cancers. Proc Natl Acad Sci U S A 1996;93(1):136-140.

60. Hassan R, Bera T, Pastan I. Mesothelin: a new target for immunotherapy. Clin Cancer Res 2004;10(12 Pt 1):39373942.

61. Hassan R, Schweizer C, Lu KF, Schuler B, Remaley AT, Weil SC, et al. Inhibition of mesothelin-CA-125 interaction in patients with mesothelioma by the anti-mesothelin monoclonal antibody MORAb-009: Implications for cancer therapy. Lung Cancer 2010;68(3):455-459.

62. Laheru D, Cohen J, Phillips M. A phase I study of MORab-009, a monoclonal antibody against mesothelin, in mesothelioma, pancreatic and ovarian cancer. J Clin Oncol 2008;26:15.

63. An Efficacy Study of MORAb-009 Amatuximab in Subjects With Pleural Mesothelioma. http://www.clinicaltrials.gov

64. Mikulski SM, Costanzi JJ, Vogelzang NJ, McCachren S, Taub RN, Chun H, et al. Phase II trial of a single weekly intravenous dose of ranpirnase in patients with unresectable malignant mesothelioma. J Clin Oncol 2002;20(1):274-281.

65. Reck M, Krzakowski M, Jassem J. Randomized, multicenter phase III study of ranpirnase plus doxorubicin (DOX) versus DOX in patients with unresectable malignant mesothelioma (MM). J Clin Oncol 2009;27:15.

66. Mittelman A, Puccio C, Gafney E, Coombe N, Singh B, Wood D, et al. A phase I pharmacokinetic study of recombinant human tumor necrosis factor administered by a 5-day continuous infusion. Invest New Drugs 1992;10(3):183-190.

67. Creaven PJ, Brenner DE, Cowens JW, Huben RP, Wolf RM, Takita H, et al. A phase I clinical trial of recombinant human tumor necrosis factor given daily for five days. Cancer Chemother Pharmacol 1989;23(3):186-191.

68. Lejeune FJ, Liénard D, Matter M, Rüegg C. Efficiency of recombinant human TNF in human cancer therapy. Cancer Immun 2006;6:6.

69. Gregorc V, Zucali PA, Santoro A, Ceresoli GL, Citterio G, De Pas TM, et al. Phase II study of asparagine-glycinearginine-human tumor necrosis factor alpha, a selective vascular targeting agent, in previously treated patients with malignant pleural mesothelioma. J Clin Oncol 2010;28(15):2604-2611.

70. NGR015: Study in Second Line for Patient With Advanced Malignant Pleural Mesothelioma Pretreated With Pemetrexed. www.clinicaltrials.gov 
71. Marks PA, Richon VM, Miller T, Kelly WK. Histone deacetylase inhibitors. Adv Cancer Res 2004;91:137-168.

72. Frew AJ, Johnstone RW, Bolden JE. Enhancing the apoptotic and therapeutic effects of HDAC inhibitors. Cancer Lett 2009;280(2):125-133.

73. Kelly WK, O'Connor OA, Krug LM, Chiao JH, Heaney M, Curley T, et al. Phase I study of an oral histone deacetylase inhibitor, suberoylanilide hydroxamic acid, in patients with advanced cancer. J Clin Oncol 2005;23(17):3923-3931.

74. Ramalingam SS, Parise RA, Ramanathan RK, Ramananthan RK, Lagattuta TF, Musguire LA, et al. Phase I and pharmacokinetic study of vorinostat, a histone deacetylase inhibitor, in combination with carboplatin and paclitaxel for advanced solid malignancies. Clin Cancer Res 2007;13(12):3605-3610.

75. Suberoylanilide Hydroxamic Acid (Vorinostat, MK-0683) Versus Placebo in Advanced Malignant Pleural Mesothelioma (0683-014 AM5, EXT1). http://www.clinicaltrials.gov

76. Ramalingam SS, Belani CP, Ruel C, Frankel P, Gitlitz B, Koczywas M, et al. Phase II study of belinostat (PXD101), a histone deacetylase inhibitor, for second line therapy of advanced malignant pleural mesothelioma. J Thorac Oncol 2009;4(1):97-101.

77. Scherpereel A, Berghmans T, Lafitte JJ, Colinet B, Richez M, Bonduelle Y, et al. Valproate-doxorubicin: promising therapy for progressing mesothelioma. A phase II study. Eur Respir J 2011;37(1):129-135.

78. Shapiro GI, Tibes R, Gordon MS, Wong BY, Eder JP, Borad MJ, et al. Phase I Studies of CBP501, a G2 Checkpoint Abrogator, as Monotherapy and in Combination with Cisplatin in Patients with Advanced Solid Tumors. Clin Cancer Res 2011;

79. Kai K, D'Costa S, Sills RC, Kim Y. Inhibition of the insulin-like growth factor 1 receptor pathway enhances the antitumor effect of cisplatin in human malignant mesothelioma cell lines. Cancer Lett 2009;278(1):49-55.

80. Pazopanib in Treating Patients With Malignant Pleural Mesothelioma. www.clinicaltrials.gov

81. Axitinib in Malignant Mesothelioma (N08CPA). www.clinicaltrials.gov

82. Sartore-Bianchi A, Gasparri F, Galvani A, Nici L, Darnowski JW, Barbone D, et al. Bortezomib inhibits nuclear factor-kappaB dependent survival and has potent in vivo activity in mesothelioma. Clin Cancer Res 2007;13(19):59425951.

83. Bortezomib in Treating Patients With Malignant Pleural Mesothelioma. www.clinicaltrials.gov

84. Gordon GJ, Mani M, Maulik G, Mukhopadhyay L, Yeap BY, Kindler HL, et al. Preclinical studies of the proteasome inhibitor bortezomib in malignant pleural mesothelioma. Cancer Chemother Pharmacol 2008;61(4):549-558.

85. Bortezomib and Cisplatin as First-Line Therapy in Treating Patients With Malignant Mesothelioma. www.clinicaltrials.gov

86. A Study of Cetuximab Combined With Cisplatin or Carboplatin/Pemetrexed as First Line Treatment in Patients With Malignant Pleural Mesothelioma. (MesoMab). www.clinicaltrials.gov

87. Phase I Dose-Escalation Study Of Azacitidine In Combination With Temozolomide. www.clinicaltrials.gov

88. Sandler A, Gray R, Perry MC, Brahmer J, Schiller JH, Dowlati A, et al. Paclitaxel-carboplatin alone or with bevacizumab for non-small-cell lung cancer. N Engl J Med 2006;355(24):2542-2550.

89. Johnson D, Fehrenbacher L, Novotny W. Randomized phase II Trial comparing bevacizumab plus carboplatin and paclitaxel with carboplatin and paclitaxel alone in previously untreated locally advanced or metastatic non-small-cell lung cancer. J Clin Oncol 2004;22:2184-2191. 
90. Hurwitz H, Fehrenbacher L, Novotny W, Cartwright T, Hainsworth J, Heim W, et al. Bevacizumab plus irinotecan, fluorouracil, and leucovorin for metastatic colorectal cancer. N Engl J Med 2004;350(23):2335-2342.

91. Frederick PJ, Straughn JM, Alvarez RD, Buchsbaum DJ. Preclinical studies and clinical utilization of monoclonal antibodies in epithelial ovarian cancer. Gynecol Oncol 2009;113(3):384-390.

92. Miller K, Wang M, Gralow J, Dickler M, Cobleigh M, Perez EA, et al. Paclitaxel plus bevacizumab versus paclitaxel alone for metastatic breast cancer. N Engl J Med 2007;357(26):2666-2676.

93. Zuniga RM, Torcuator R, Jain R, Anderson J, Doyle T, Ellika S, et al. Efficacy, safety and patterns of response and recurrence in patients with recurrent high-grade gliomas treated with bevacizumab plus irinotecan. J Neurooncol 2009;91(3):329-336.

94. Maemondo M, Inoue A, Kobayashi K, Sugawara S, Oizumi S, Isobe H, et al. Gefitinib or chemotherapy for nonsmall-cell lung cancer with mutated EGFR. N Engl J Med 2010;362(25):2380-2388.

95. Whitehead J. Stopping clinical trials by design. Nat Rev Drug Discov 2004;3(11):973-977.

96. Demetri GD, von Mehren M, Blanke CD, Van den Abbeele AD, Eisenberg B, Roberts PJ, et al. Efficacy and safety of imatinib mesylate in advanced gastrointestinal stromal tumors. N Engl J Med 2002;347(7):472-480.

97. Mol CD, Dougan DR, Schneider TR, Skene RJ, Kraus ML, Scheibe DN, et al. Structural basis for the autoinhibition and STI-571 inhibition of c-Kit tyrosine kinase. J Biol Chem 2004;279(30):31655-31663.

98. Byrne MJ, Nowak AK. Modified RECIST criteria for assessment of response in malignant pleural mesothelioma. Ann Oncol 2004;15(2):257-260.

99. Basu S, Saboury B, Torigian DA, Alavi A. Current Evidence Base of FDG-PET/CT Imaging in the Clinical Management of Malignant Pleural Mesothelioma: Emerging Significance of Image Segmentation and Global Disease Assessment. Mol Imaging Biol 2010;

100. Federal Drug Administration. Guidance for industry. Clinical trials endpoints for the approval of Cancer Drugs and Biologics. Rockville, MD: UD Department of Health and Human Services. 2007;2007

101. Di Leo A, Bleiberg H, Buyse M. Overall survival is not a realistic end point for clinical trials of new drugs in advanced solid tumors: a critical assessment based on recently reported phase III trials in colorectal and breast cancer. J Clin Oncol 2003;21(10):2045-2047.

102. Francart J, Legrand C, Sylvester R, Van Glabbeke M, van Meerbeeck JP, Robert A, et al. Progression-free survival rate as primary end point for phase II cancer clinical trials: application to mesothelioma--The EORTC Lung Cancer Group. J Clin Oncol 2006;24(19):3007-3012.

103. Haas-Kogan DA, Prados MD, Tihan T, Eberhard DA, Jelluma N, Arvold ND, et al. Epidermal growth factor receptor, protein kinase B/Akt, and glioma response to erlotinib. Journal of the National Cancer Institute 2005;97(12):880-887.

104. Bang Y, Kwak L, Shaw A. Clinical activity of the oral ALK inhibitor PF-02341066 in ALK-positive patients with non-small cell lung cancer (NSCLC). J Clin Oncol 2010;28:18. 